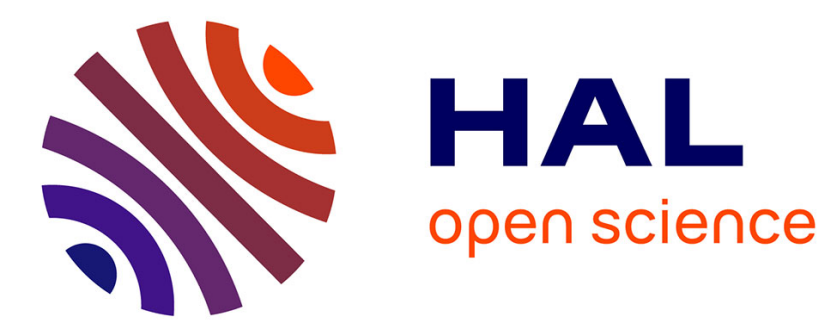

\title{
Les accidents climatiques brutaux et localisés et leurs conséquences
}

\author{
Jean-Claude Duplessy
}

\section{To cite this version:}

Jean-Claude Duplessy. Les accidents climatiques brutaux et localisés et leurs conséquences. Comptes Rendus Géoscience, 2005, 337 (10-11), pp.881-887. 10.1016/j.crte.2005.04.008 . hal-02958053

\section{HAL Id: hal-02958053 \\ https://hal.science/hal-02958053}

Submitted on 9 Oct 2020

HAL is a multi-disciplinary open access archive for the deposit and dissemination of scientific research documents, whether they are published or not. The documents may come from teaching and research institutions in France or abroad, or from public or private research centers.
L'archive ouverte pluridisciplinaire HAL, est destinée au dépôt et à la diffusion de documents scientifiques de niveau recherche, publiés ou non, émanant des établissements d'enseignement et de recherche français ou étrangers, des laboratoires publics ou privés. 


\section{Les accidents climatiques brutaux et localisés et leurs conséquences}

\section{Abrupt and localized climatic changes and their consequences}

\section{Avant-propos}

La fondation Louis D de l'Institut de France a sélectionné comme thématique pour l'année 2004 «les accidents climatiques brutaux et localisés et leurs conséquences » et le jury scientifique a proposé de décerner son prix au groupe «Climat» du Laboratoire des sciences du climat et de l'environnement (LSCE).

Au cours des dernières années, ce laboratoire mixte du Commissariat à l'énergie atomique et du Centre national de la recherche scientifique a contribué à plusieurs aspects importants de cette recherche.

Le LSCE, dans le cadre de larges collaborations nationales et internationales, a contribué à mettre en évidence l'existence, pendant la dernière glaciation, de variations rapides de la température de l'air en Europe de l'Ouest comme au Groenland, connues sous le nom d'événements de Dansgaard-Oeschger [21]. Il a montré que ces événements étaient associés à des changements de circulation océanique dans l'Atlantique nord $[8,12,14,17,46]$. Une approche pluridisciplinaire a permis de dater ces accidents brutaux $[4,18]$ qui peuvent se développer en moins d'un siècle, une durée comparable à celle d'une vie humaine [45].

Les archives océaniques, glaciaires et continentales montrent la vaste extension géographique des changements abrupts du climat $[10,18,38,48]$. Enfin, une hiérarchie de modèles de la dynamique du climat, allant de modèles conceptuels à des modèles de circulation générale de l'atmosphère et de l'océan, a été mise en œuvre pour tester les mécanismes potentiel-

\section{Foreword}

The 'Louis D foundation of the Institut de France' has selected as a topic for the year 2004 'Abrupt and localized climatic changes and their consequences'. The Scientific Committee has proposed to give its prize to the 'Climate' group of the 'Laboratoire des sciences du climat et de l'environnement' (LSCE). Over the last few years, this joint laboratory of the French 'Commissariat à l'énergie atomique' and 'Centre national de la recherche scientifique' has significantly contributed to several aspects of this topic.

Within the framework of numerous national and international collaborations, scientists from LSCE have contributed to reveal the occurrence of abrupt air temperature variations over western Europe and Greenland (Dansgaard-Oeschger events) [21] and provided evidence that they were related to major circulation changes in the North Atlantic Ocean $[8,12,14,17,46]$. A multi-proxy approach has been used to generate a chronology for these events $[4,18]$, which have sometimes developed within less than a century [45], i.e. the duration of a human life.

Marine, continental and polar ice records have shown the broad extension of these abrupt climatic changes $[10,18,38,48]$. Finally, mechanisms that may be potentially responsible for these events have been identified and tested using a variety of climate models, ranging from conceptual models to coupled oceanatmosphere general circulation models. Freshwater injection in the high latitudes, originating from mas- 
lement responsables de ces accidents climatiques. La sensibilité de la circulation océanique dans l'Atlantique nord à un apport accru d'eau douce, provenant en période glaciaire de la fonte catastrophique des calottes avec des débâcles massives d'icebergs (les événements de Heinrich), est apparue comme un facteur essentiel [34-36,44].

Aux échelles de temps plus courtes, le LSCE a apporté des résultats originaux sur la variabilité du climat au cours des derniers siècles. Il a développé des méthodes permettant d'interpréter des séries de données historiques, comme les dates de vendanges, en termes climatiques [9], analysé les relations entre les régimes de temps sur l'Atlantique nord et les événements extrêmes [49] et appliqué la théorie des extrêmes pour évaluer les incertitudes qui sont associées à toute analyse d'événements extrêmes dans le cadre des recherches climatiques [25,32].

Les émissions de gaz à effet de serre résultant des activités humaines ont déjà perturbé l'équilibre radiatif de l'atmosphère et l'évolution du climat de notre planète $[13,20,39,40]$, même si les effets du changement climatique ne se feront sentir que progressivement, mais avec de plus en plus d'acuité [2]. Cependant, de nombreuses incertitudes subsistent $[1,3,29,37$, 41]. Même si tous les modèles simulent un réchauffement progressif au cours du prochain siècle, ceci n'exclut pas que des modifications soudaines et de grande amplitude du système climatique puissent survenir, entraînant un bouleversement de nos conditions de vie $[13,21]$. Ce sont les «surprises » dont le rapport de l'IPCC a reconnu la potentialité [20].

Aujourd'hui, la communauté scientifique doit estimer la probabilité de ces surprises et simuler les effets de celles qui auront été reconnues comme des scénarios vraisemblables. Or, nous ne connaissons probablement pas tous les mécanismes susceptibles de générer des variations climatiques brutales. C'est pourquoi un effort de recherche, tant sur les données passées que sur leur modélisation, reste indispensable. L'objet du présent numéro thématique est de présenter quelquesuns des résultats les plus récents acquis par les équipes récipiendaires du prix Louis D de l'Institut de France et de montrer comment ils contribuent à mieux comprendre le comportement de ce système de haute complexité qu'est l'ensemble interactif constitué de l'atmosphère, l'océan, les glaces, la surface des continents et les cycles biogéochimiques. sive iceberg discharges by ice sheets during glacial conditions (Heinrich events) appears as a major forcing factor perturbing the North Atlantic circulation [34-36,44].

On shorter time scales, scientists from LSCE have brought new insight on the climate variability of the last centuries. They have developed methodologies allowing to generate climatic series from historical data, such as harvest dates [9], and determined the relationship between typical states of the atmospheric circulation over the North Atlantic and extreme events [49]. They have also applied the Extreme Value Theory to assess the uncertainty associated with extreme events in a wide range of climatic studies [25,32].

Anthropogenic emissions of greenhouse gases have already perturbed the radiative equilibrium of the atmosphere and the climate evolution [13,20,39,40], and the effects of climate change are expected to be felt progressively with an increasing intensity [2]. However, uncertainties are still numerous [1,3,29,37,41]. Even if all models simulate a progressive warming during the next century, abrupt and large amplitude reorganizations of the climate system cannot be ruled out, leading to major changes of our life conditions $[13,21]$. These potential changes were recognized and called 'surprises' in the IPCC report [20].

The scientific community has the duty to estimate the probability of such surprises. However, we probably still do not know all the mechanisms that may generate abrupt climatic variations. Efforts need to be devoted to their study, including reconstruction of past climates and their simulation with models of various degrees of complexity. This special issue includes recent work achieved by the scientific teams who received the award 'Prix Louis D de l'Institut de France' with the aim of a better understanding of the behaviour of this highly complex system made of the atmosphere, the ocean, ice and ice sheets, continental surface and biogeochemical cycles and their interactions.

The occurrence of abrupt climate changes does not rule out the astronomical theory of palaeoclimates [15]. As a matter of fact, the earth's climate is triggered by seasonal insolation changes linked to changes of the Earth's orbit around the sun [5,6]. However, the climate system is also prone to large and abrupt reorganizations, which deeply modify the ocean and atmospheric circulation, the air temperature and the hydrological cycle, with a large impact on the vege- 
L'existence de variations climatiques abruptes ne remet pas en cause la théorie astronomique des paléoclimats [15]. Le climat de notre planète répond bien aux variations saisonnières de l'insolation dues aux petites modifications de l'orbite que la terre décrit autour du soleil $[5,6]$. Cependant, le système climatique est susceptible de subir des réorganisations soudaines, qui entraînent un bouleversement de la circulation de l'océan et de l'atmosphère, des températures et du cycle hydrologique, avec des conséquences majeures sur la végétation. Cortijo et al. [11], Kissel [26] et Labeyrie et al. [27] illustrent les modifications de la circulation océanique superficielle et profonde qui affectent l'océan Atlantique, lorsque les calottes glaciaires qui avaient envahi son plateau continental dans les hautes latitudes relâchaient des quantités massives d'icebergs. D'un épisode de fonte à un autre, les trajectoires des icebergs diffèrent en fonction de leur origine [11]. Roche et Paillard [43] interprètent les données isotopiques de l'événement de Heinrich H4. Ils montrent que la zone de fonte était limitée à une bande comprise entre $45^{\circ} \mathrm{N}$ et $55^{\circ} \mathrm{N}$ et que ce sont les variations de température qui ont été responsables de l'essentiel du signal isotopique enregistré dans les sédiments marins en dehors de cette zone.

Les forages effectués dans les calottes glaciaires constituent un outil de choix pour documenter les variations de la circulation et de la composition de l'atmosphère [42]. Masson-Delmotte et al. [31] montrent qu'après le dernier interglaciaire (Éémien), qui avait été plus chaud que l'Actuel d'environ $5^{\circ} \mathrm{C}$ au Groenland, des variations abruptes de la température de l'air au-dessus du Groenland apparaissent peu après l'entrée en glaciation, alors que le volume des calottes glaciaires représentait seulement un tiers de celui du maximum glaciaire. En sortie de glaciation, un coup de froid brutal, d'une durée brève, a été ressenti, il y a seulement 8200 ans au Groenland et en Europe [47], ainsi que dans l'Atlantique nord [16,30]. Expliqué par la débâcle de la calotte glaciaire résiduelle qui recouvrait le baie d'Hudson [47], cet événement confirme la vulnérabilité du système climatique à des perturbations du bilan hydrologique de l'Atlantique nord. Landais et al. [28] montrent que les changements rapides de température au Groenland ont une amplitude comprise entre $10^{\circ} \mathrm{C}$ et $16^{\circ} \mathrm{C}$, bien plus importante que ne le suggéraient les rapports ${ }^{18} \mathrm{O} /{ }^{16} \mathrm{O}$ et $\mathrm{D} / \mathrm{H}$ de la glace, en raison d'un changement de saisonnalité des tation. Cortijo et al. [11], Kissel [26] and Labeyrie et al. [27] describe the surface and deep-water circulation changes, which occur in response to massive iceberg discharges released by the Laurentide and European ice sheets. The meltwater area differs according to the origin of icebergs [11]. Roche et Paillard [43] use an Earth model of intermediate complexity to show that, during Heinrich event-4, most icebergs melted in the $45^{\circ} \mathrm{N}-55^{\circ} \mathrm{N}$ latitudinal band and that the isotope signal measured outside of this area in North Atlantic sediment cores reflects mainly sea surface temperature variations.

Deep ice coring provides unique archives to document atmospheric composition and circulation variations [42]. Masson-Delmotte et al. [31] show that the last interglacial (Eemian), which was about $5{ }^{\circ} \mathrm{C}$ warmer than today in Greenland, was followed by abrupt air temperature variations, which began when the continental ice volume was as low as one third of that of the last glacial maximum. When the glaciation was almost over, an abrupt cooling of short duration occurred in Greenland and in Europe about 8200 years ago [47] as well as in the North Atlantic $[16,30]$. This climatic event is best explained by the injection into the Labrador Sea of meltwater released by the residual Laurentide ice sheet, which was located over Hudson Bay [47]. The amount of ice involved in this event is small and reflects the high sensitivity of the climate system. Landais et al. [28] demonstrate that the ${ }^{18} \mathrm{O} /{ }^{16} \mathrm{O}$ and $\mathrm{D} / \mathrm{H}$ ratios of the ice do not fully record the magnitude of the mean annual temperature variations as a result of changes in the hydrological cycle, i.e. precipitation seasonality and moisture sources. Jouzel et al. [22] interpret the deuterium excess of the ice to show that the sea-surface temperature in the moisture sources was higher when the air temperature over Greenland was colder. This paradox is only apparent: during the cold events, precipitation originates from lower and warmer latitudes than during warm events.

Temperature variations over the North Atlantic Ocean have a large impact over atmospheric circulation and European vegetation. Genty et al. [19] provide evidence for these changes from palaeoclimatic records derived from loess, pollen and cave concretions. The latter are absolutely dated by the uraniumthorium method. The response of the vegetation to climatic changes is strong: an abrupt warming coin- 
précipitations et d'un déplacement des zones où s'évapore l'eau de mer qui alimente les précipitations sur le Groenland. Jouzel et al. [22] précisent le déplacement de ces zones à l'aide des fluctuations de l'excès en deutérium des glaces et montrent que la température des zones d'évaporation est plus élevée au moment des paroxysmes de froid sur le Groenland. Le paradoxe n'est qu'apparent : les précipitations sont alors alimentées par des eaux évaporées depuis des zones de plus basses latitudes qu'en période chaude, et donc avec des températures plus élevées au point source.

Les variations de température sur l'océan Atlantique nord ont eu un impact considérable sur la circulation atmosphérique et la végétation européenne. Genty et al. [19] montrent qu'on en retrouve la trace dans de nombreux indicateurs paléoclimatiques, comme les loess, les pollens et les concrétions des cavernes, qui présentent l'avantage de pouvoir être datées directement par la méthode uranium-thorium. La végétation répond aux fluctuations du climat et témoigne qu'un réchauffement brutal s'accompagne du passage d'une steppe semi-désertique à des conditions humides permettant le développement des arbres et une activité pédobiologique intense. Kageyama et al. [24] utilisent un modèle de circulation générale de l'atmosphère, couplé à un modèle de végétation, pour simuler la perturbation climatique, associée à la grande débâcle glaciaire qui a marqué le début de la déglaciation. En bon accord avec les données, le modèle, qui simule une végétation herbacée avec quelques arbres d'altitude au moment du maximum de volume des calottes glaciaires, montre l'établissement d'une steppe semidésertique au paroxysme de la débâcle des icebergs vêlés par les calottes glaciaires en voie de disparition.

Cependant, nous sommes loin d'avoir compris l'origine des variations climatiques abruptes. Le rôle de l'océan paraît certain en raison de sa capacité calorifique. Il explique la persistance des changements et une réponse différée de quelques siècles des hautes latitudes de l'hémisphère sud [7]. Plusieurs mécanismes ont été avancés pour expliquer ces bascules climatiques brutales. Ils font le plus souvent appel à des oscillations forcées du système atmosphère-océancalottes glaciaires ou à des instabilités des calottes glaciaires, de la circulation océanique ou du système couplé atmosphère-océan-calottes glaciaires. C'est cette dernière hypothèse que Kageyama et Paillard [23] examinent à l'aide d'un modèle climatique de cides with the disappearance of steppic polar desert, which is replaced by humid temperate vegetation with trees and active soil activity. Kageyama et al. [24] use a general circulation model of the atmosphere coupled to a vegetation model to simulate the climatic variations resulting from the massive iceberg discharge, which marked the beginning of the deglaciation. In good agreement with pollen data, the model simulates herbaceous vegetation with a few mountain trees during the glacial maximum and a steppic polar desert during the peak of iceberg discharge.

However, we are far from a full understanding of abrupt climatic changes. The implication of the ocean is obvious due to its high caloric capacity and explains both the persistence and delayed response of the Southern Hemisphere to changes in the Northern Hemisphere [7]. Several mechanisms have been proposed to explain these changes. They relate either to forced oscillations of the atmosphere-ocean-ice sheet system or to instabilities of the ice sheets, the ocean circulation, or the coupled atmosphere-ocean-ice sheet system. This last hypothesis is examined by Kageyama and Paillard [23], who used an Earth model of intermediate complexity coupled to a simple model of Scandinavian ice sheet. They show that an internal oscillation of the climate system is possible only if the ocean is very close to the threshold in which it switches from one mode of thermohaline circulation to another. This result raises therefore new questions on the ocean behaviour. We still do not know the whole set of interactions within the climate system, which may be responsible for rapid changes of the global atmospheric circulation.

The climatic variability of the last few centuries is much smaller than that of the glaciation, but past human societies were vulnerable to these changes. Yiou and Masson-Delmotte [50] generated several records for Europe derived from various proxies such as isotopic analysis of tree rings or historical records. The whole set of records indicates major changes in the seasonal cycle, atmospheric circulation and frequency of extreme events. Although these variations were small compared to those of the geological past, they were so deeply resented by human societies that historians called 'Little Ice Age' the period extending from the 17th to the 19th century. The vulnerability of human societies today is a fact that has clearly been registered by insurance companies. Extreme events 
complexité intermédiaire, couplé à un modèle simple de la calotte fennoscandienne. Ils montrent qu'une oscillation interne du système climatique n'est vraisemblable que si l'océan est lui-même dans un état proche de l'instabilité, ce qui pose de nouvelles questions sur le comportement de l'océan. On ne connaît donc pas encore l'ensemble des interactions au sein du système climatique, qui permettent un changement rapide de la circulation atmosphérique générale.

La variabilité climatique des derniers siècles a été beaucoup plus faible que celle de la dernière glaciation, mais de nombreuses archives historiques témoignent de la vulnérabilité des sociétés humaines. Yiou et Masson-Delmotte [50] présentent un ensemble de séries temporelles décrivant l'évolution du climat des derniers siècles en Europe. Celles-ci sont dérivées d'indicateurs très diversifiés, comme l'analyse isotopique des anneaux d'arbres ou des données historiques. Elles témoignent des modifications profondes qui ont affecté le cycle saisonnier, la circulation atmosphérique et la fréquence des événements extrêmes. Ces variations, modestes par rapport à celles que documentent les enregistrements géologiques, ont eu cependant d'importantes répercussions sur les sociétés, au point que les historiens ont désigné la période qui s'étend du XVII ${ }^{\mathrm{e}}$ au XIX ${ }^{\mathrm{e}}$ siècle sous l'expression imagée de petit âge glaciaire. La vulnérabilité des sociétés humaines aux vicissitudes du climat est un fait avéré, que les sociétés d'assurance ont déjà intégré. Ce sont les événements exceptionnels (fortes tempêtes, sécheresses prolongées, inondations) qui ont le plus fort impact. Or, détecter des changements de leur fréquence nécessite une analyse statistique complexe. Naveau et al. [33] présentent différentes approches issues de la théorie des extrêmes, qui devraient constituer des outils efficaces pour aborder ce problème.

L'étude des climats passés a ainsi conduit à la découverte inattendue de l'existence de bouleversements rapides au sein du système climatique. Les articles rassemblés dans ce numéro thématique illustrent la diversité et la complexité des phénomènes et des mécanismes entrant en jeu à ces occasions. Leur prévision, dans le cadre du changement climatique induit pas les activités humaines, constitue un défi que la communauté scientifique doit relever, en raison de son importance sociétale.

Jean-Claude Duplessy

Disponible sur Internet le 29 juin 2005 (storms, long droughts, floods) have the strongest impact on society. As they are rare, detecting a change of their frequency requires a complex statistical analysis. Naveau et al. [33] describe several approaches issued from Extreme Value Theory, designed to be efficiently applied to climatic problems.

The study of past climates has thus led to the unexpected discovery of rapid changes within the climate system. The papers included in this special issue provide examples of the great diversity and complexity of the involved phenomena and mechanisms. Potential abrupt variations as a consequence of the humaninduced climate change could have such a large impact on society that their forecast must be a major goal for the scientific community.

Jean-Claude Duplessy 


\section{Références / References}

[1] W.N. Adger, K. Vincent, Uncertainty in adaptative capacity, C. R. Geoscience 337 (2005) 399-410.

[2] J.C. André, Réflexions sur le calendrier du débât Energies et Climat, C. R. Acad. Sci. Paris, Ser. IIa (2001) 835-839.

[3] J.-C. André, Sur la crédibilité des conséquences de l'effet de serre, C. R. Geoscience 335 (2003) 503-507.

[4] E. Bard, M. Arnold, P. Maurice, J. Duprat, J. Moyes, J.-C. Duplessy, Retreat velocity of the North Atlantic polar front during the last deglaciation determined by ${ }^{14} \mathrm{C}$ accelerator mass spectrometry, Nature 328 (1987) 791-794.

[5] A.L. Berger, Long-term variations of caloric insolation resulting from the Earth's orbital elements, Quat. Res. 9 (1978) 139-167.

[6] A.L. Berger, M.-F. Loutre, Théorie astronomique des paléoclimats, C. R. Geoscience 336 (2004) 701-709.

[7] T. Blunier, J. Chappellaz, J. Schwander, A. Dällenbach, B. Stauffer, T. Stocker, D. Raynaud, J. Jouzel, H.B. Clausen, C.U. Hammer, S.J. Johnson, Asynchrony of Antarctica and Greenland climate change during the last glacial period, Nature 394 (1998) 739-743.

[8] G. Bond, W.S. Broecker, S. Johnsen, J. McManus, L. Labeyrie, J. Jouzel, G. Bonani, Correlations between climate records from North Atlantic sediments and Greenland ice, Nature 365 (1993) 143-147.

[9] I. Chuine, P. Yiou, N. Viovy, B. Seguin, V. Daux, E. Le Roy Ladurie, Grape harvest dates and temperature variations in France since 1370, Nature 432 (2004) 289-290.

[10] N. Combourieu-Nebout, J.L. Turon, R. Zahn, L. Capotondi, L. Londeix, K. Pahnke, Enhanced aridity and atmospheric high-pressure stability over the western Mediterranean during the North Atlantic cold events of the last $50 \mathrm{ky}$, Geology 30 (10) (2002) 863-866.

[11] E. Cortijo, J.-C. Duplessy, L. Labeyrie, J. Duprat, D. Paillard, Les événements de Heinrich : impact hydrologique, C. R. Geoscience 337 (2005); 10.1016/j.crte.2005.04.011.

[12] E. Cortijo, L. Labeyrie, L. Vidal, M. Vautravers, M. Chapman, J.-C. Duplessy, M. Elliot, M. Arnold, J.-L. Turon, G. Auffret, Changes in sea surface hydrology associated with Heinrich event 4 in the North Atlantic Ocean between $40^{\circ} \mathrm{N}$ and $60^{\circ} \mathrm{N}$, Earth Planet. Sci. Lett. 146 (1997) 29-45.

[13] J.-C. Duplessy, État des connaissances et incertitudes sur le changement climatique induit par les activités humaines, C. R. Acad. Sci. Paris, Ser. IIa 333 (2001) 765-773.

[14] J.-C. Duplessy, La circulation globale de l'océan et ses variations dans le passé, C. R. Geoscience 336 (2004) 657-666.

[15] J.-C. Duplessy, Reconstructing the variability of the climatic system: Facts and Theories, C. R. Geoscience 337 (2005); 10.1016/j.crte.2005.04.005.

[16] J.-C. Duplessy, E. Ivanova, I. Murdmaa, M. Paterne, L. Labeyrie, Holocene paleoceanography of the northern Barents Sea and variations of the northward heat transport by the Atlantic Ocean, Boreas 30 (2001) 2-16.

[17] M. Elliot, L. Labeyrie, J.-C. Duplessy, Changes in North Atlantic deep-water formation associated with the DansgaardPoeschger temperature oscillations (60-10 ka), Quat. Sci. Rev. 21 (2002) 1153-1165.
[18] D. Genty, D. Blamart, R. Ouahdi, M. Gilmour, A. Baker, J. Jouzel, S. Van-Exter, Precise dating of Dansgaard-Oeschger climate oscillations in western Europe from stalagmite data, Nature 421 (2003) 833-837.

[19] D. Genty, N. Combourieu-Nebout, C. Hatté, D. Blamart, B. Ghaleb, L. Isabello, Rapid climatic changes of the last 90 kyr recorded on the European continent, C. R. Geoscience 337 (2005); 10.1016/j.crte.2005.04.010.

[20] IPCC, Third Assessment Report, Cambridge University Press, 2001, $881 \mathrm{p}$.

[21] J. Jouzel, C. Lorius, Evolution du climat : du passé récent vers le futur, C. R. Acad. Sci. Paris, Ser. IIa 328 (1999) 229 239.

[22] J. Jouzel, V. Masson-Delmotte, M. Stievenard, A. Landais, F. Vimeux, S.J. Johnsen, A. Sveinbjornsdottir, J.W.C. White, Rapid deuterium-excess changes in Greenland ice cores: a link between the ocean and the atmosphere, C. R. Geoscience 337 (2005).

[23] M. Kageyama, D. Paillard, Dansgaard-Oeschger events: an oscillation of the climate-ice-sheet system?, C. R. Geoscience 337 (2005); 10.1016/j.crte.2005.04.013.

[24] M. Kageyama, N. Combourieu-Nebout, P. Sepulchre, O. Peyron, G. Krinner, G. Ramstein, J.-P. Cazet, The Last Glacial Maximum and Heinrich Event 1 in terms of climate and vegetation around the Alboran Sea: a preliminary model-data comparison, C. R. Geoscience 337 (2005); 10.1016/j.crte.2005.04.012.

[25] R. Katz, M. Parlange, P. Naveau, Extremes in hydrology, Adv. Water Ressour. 25 (2002) 1287-1304.

[26] C. Kissel, Magnetic signature of rapid climatic variations in glacial North Atlantic: a review, C. R. Geoscience 337 (2005); 10.1016/j.crte.2005.04.009.

[27] L. Labeyrie, C. Waelbroeck, E. Cortijo, E. Michel, J.C. Duplessy, Changes in deep water hydrology during the last deglaciation, C. R. Geoscience 337 (2005).

[28] A. Landais, J. Jouzel, V. Masson-Delmotte, N. Caillon, Large temperature variations over rapid climatic events in Greenland: a method based on air isotopic measurements, C. R. Geoscience 337 (2005); 10.1016/j.crte.2005.04.003.

[29] H. Le Treut, Les scénaros globaux de changement climatique et leurs incertitudes, C. R. Geoscience 335 (2003) 525-533.

[30] O. Marchal, I. Cacho, T. Stocker, J. Grimalt, E. Calvo, B. Martrat, N.J. Shackleton, M. Vautravers, E. Cortijo, S. Van Krefeld, C. Andersson, N. Koc, M. Chapman, L. Sbaffi, J.C. Duplessy, M. Sarnthein, J.L. Turon, J. Duprat, E. Jansen, Apparent longterm cooling of the sea surface in the northeastern Atlantic and the Mediterranean during the Holocene, Quat. Sci. Rev. 21 (2002) 455-483.

[31] V. Masson-Delmotte, A. Landais, N. Combourieu-Nebout, U. von Grafenstein, J. Jouzel, N. Caillon, J. Chappellaz, D. Dahl-Jenssen, S.J. Johnsen, B. Stenni, Rapid climate variability during warm and cold periods in polar regions and Europe, C. R. Geoscience 337 (2005); 10.1016/j.crte.2005.04.001.

[32] P. Naveau, C.M. Ammann, Statistical distributions of ice core sulfate from climatically relevant volcanic eruptions, Geophys. Res. Lett. 32 (in press). 
[33] P. Naveau, M. Nogaj, C.M. Ammann, P. Yiou, D. Cooley, V. Jomelli, Statistical methods for the analysis of climate extremes, C. R. Geoscience 337 (2005); 10.1016/j.crte.2005.04.015.

[34] D. Paillard, Modèles simplifiés pour l'étude de la variabilité de la circulation thermohaline au cours des cycles glaciaireinterglaciaire, thèse, université Paris-11-Orsay, France, 1995.

[35] D. Paillard, E. Cortijo, A simulation of the Atlantic meridional circulation during Heinrich event 4 using reconstructed sea surface temperatures and salinities, Paleoceanography 14 (6) (1999) 716-724.

[36] D. Paillard, L. Labeyrie, Role of the thermohaline circulation in the abrupt warming after Heinrich events, Nature 372 (1994) 162-164.

[37] A. Patt, R.J.T. Klein, A. de la Vega-Leinert, Taking the uncertainty in climate-change vulnerability assessment seriously, C. R. Geoscience 337 (2005) 411-424.

[38] L.C. Petersen, G.H. Haug, K.A. Hughen, U. Röhl, Rapid changes in the hydrologic cycle of the tropical Atlantic during the last glacial, Science 290 (2000) 1947-1951.

[39] M. Petit, Le changement climatique d'origine humaine. Rappel de quelques résultats généraux, C. R. Acad. Sci. Paris, Ser. IIa 328 (1999) 225-227.

[40] M. Petit, L'humanité face à l'effet de serre additionnel qu'elle crée, C. R. Acad. Sci. Paris, Ser. IIa 333 (2001) 775-786.

[41] S. Planton, À l'échelle des continents : le regard des modèles, C. R. Geoscience 335 (2003) 535-543.

[42] D. Raynaud, C. Lorius, Climat et atmosphère : la mémoire des glaces, C. R. Geoscience 336 (2004) 647-656.
[43] D. Roche, D. Paillard, Modelling the oxygen-18 and glacial rapid events: a data-model comparison, C. R. Geoscience 337 (2005); 10.1016/j.crte.2005.03.019.

[44] D. Roche, D. Paillard, E. Cortijo, Constraints on the duration and freshwater release of Heinrich event 4 through isotope modelling, Nature 432 (2004) 379-382.

[45] K.C. Taylor, C.U. Hammer, R.B. Alley, H.B. Clausen, D. DahlJensen, A.J. Gow, N.S. Gundestrup, J. Kipfstuhl, J.C. Moore, E.D. Waddington, Electrical conductivity measurements from the GISP2 and GRIP Greenland ice cores, Nature 366 (1993) 549-552.

[46] L. Vidal, L. Labeyrie, E. Cortijo, M. Arnold, J.-C. Duplessy, E. Michel, S. Becqué, T.C.E. van Weering, Evidence for changes in the North Atlantic Deep Water linked to meltwater surges during the Heinrich events, Earth Planet. Sci. Lett. 146 (1997) 13-26.

[47] U. von Grafenstein, H. Erlenkeuser, J. Müller, J. Jouzel, S. Johnsen, The cold event 8200 years ago documented in oxygen isotope records of precipitation in Europe and Greenland, Clim. Dynam. 14 (1998) 73-81.

[48] Y.J. Wang, H. Cheng, R.L. Edwards, Z.S. An, J.Y. Wu, C.-C. Shen, J.A. Dorale, A high-resolution absolute-dated Late Pleistocene monsoon record from Hulu Cave, China, Science 294 (2001) 2345-2348.

[49] P. Yiou, M. Nogaj, Extreme climatic events and weather regime over the North Atlantic: When and where?, Geophys. Res. Lett. 31 (2004) L07202; 10.1029/2003GL019119.

[50] P. Yiou, V. Masson-Delmotte, Trends in sub-annual climate variability since the Little Ice Age in western Europe, C. R. Geoscience 337 (2005); 10.1016/j.crte.2005.03.016. 